\title{
都心業務地区における緑の集積が果たす環境保全に 係わる効果に関する研究
}

\section{Study on Environmental Conservation Effects of Gathered Greenery in Center Business District}

下村泰彦* 廣野 慎** 山本 聡* 増田 昇*

Yasuhiko SHIMOMURA Makoto HIRONO Satoshi YAMAMOTO Noboru MASUDA

摘要 : 本研究では, 大阪市の都心業務地区で緑が集積して存在することによる環境保全に係わる効果 を微気象, 鳥類出現, 景観評価の視点から, 緑の集積度(街路上での天空状況, $100 \mathrm{~m}$ 圈域内での緑被 率)が異なる 4 地区を対象に比較考察した。結果, 微気象に関する気温では 8 月測定から緑の集積度 が高い今橋・安土両地区の方が全時間帯で $0.6 \sim 2.7^{\circ} \mathrm{C}$ 気温上昇が抑制され, 12 月測定では 16,17 時台 で $0.2 \sim 1.2^{\circ} \mathrm{C}$ 気温低隇が抑制されること。鳥類出現では今橋地区 $(7$ 種 97 羽)が種数・個体数共に最多 であること。景観評価では『ゆとり』広がり』開放感』等の空間量や『親しみ」『美しさ』等の修 景面での評価が有意に高いこと等, 緑の集積による効果が確認できた。

\section{1.はじめに}

大都市中心部の業務地域に存在する緑は, 居住者や就業者によっ て多種多様な効果を発揮すると言われ, 自治体により街路樹や都 市公園等の公的な整備のみならず民有地緑化が推進されている。

大阪市においても一定規模以上の敷地や公開空地での緑化指導 が進められ, 都心部においても徐々にではあるが, 緑は増加傾向 にある。しかしながら, 現状の都心部における緑の分布状況は不 均一で, 点在している所もあれば, 数敷地むしくは数街区にわた り緑がまとまって確保され集積している所も確認できる。この緑 の集積程度の違いによって, 市街地内部においても環境保全面に 及ぼす効果に地域差が生じていることが考えられる。

このような背景のもと, 都心部において緑地的な視点から公開 空地内の緑地率と他の物理量との関係について探った研究”や公 園緑地を対象とした微気象に係わる効果に関する研究 ${ }^{2-5)}$ といっ た公開空地や公園緑地単体を対象としたものや, 緑地による都市 気象の緩和作用を土地被覆や緑地分布状況から区レベルで探っ $た^{6777}$ 興味深い研究が見られる。さらに, 公開空地等の民有地にお ける連続緑化が果たす環境保全に関する効果を実証した先行研究 がある ${ }^{8)}$ 。これは, 数街区にわたる街路沿いの公開空地を連続し て緑化し，線的に緑を繋げることの意義を明らかにしたものであ り, 面的に広がりのある圈域での緑については全く検討されてい なかった。しかし, 今後, 都心部において計画的に民有地緑化を 進めるにあたり, 街区内での敷地統合により 1 敷地が大規模化し てきている現状を鑑みると, 敷地単位での建築更新時に生み出さ れる公開空地での緑化の効果だけでなく, 街区といった面的な広 がりを持つ圈域での緑化の効果を探ることも重要と考えられる。

そこで本研究では, 大阪市の都心業務地において, 格子状街路 の交差点（街路中心点之呼ぶ）を基準とした周囲 4 つの街区（スー パーブロック）をおおよそ含む半径 $100 \mathrm{~m}$ 圈域を調查対象地区之 し, 緑の集積状況 (各地区内での街路の天空状況や地区内での緑 被率）の異なる 4 地区を設定した。次いで, 都市環境の改善に資 する多岐にわたる環境保全に係わる効果の中から, 微気象（気温・ 湿度), 鳥類出現状況, 景観評価に係わる効果について, 地区ご とに効果計測を行い, その調査結果を 4 地区間で比較考察するこ とにより, 緑の集積が果たす環境保全に係わる効果を探ることを 目的とした。

なお，本研究で対象とした $100 \mathrm{~m}$ 圈域は，山田ら $(1989)^{6)}$ の
研究成果である気温上昇抑制効果と $100 \mathrm{~m}$ 圈域での緑被率との相 関が高いという結果にも当てはまっている。

\section{2. 研究方法}

(1) 調査対象地区

(i) 調查対象地区の設定

調査対象地区は，大阪市の中心業務地区である船場地区の中で， 特に業務系ビルが集中して存在する土佐堀通, 本町通, 堺筋, 御 堂筋に囲まれた区域から抽出するものとした。具体的には，格子 状街路の交差点（街路中心点之呼ぶ）を基準とし，その周囲 4 つ の街区を书书よそ含む半径 $100 \mathrm{~m}$ 圈域を調查対象地区とし，緑の 集積している地区を 2 地区 (今橋地区と安土地区), 緑が集積し ていない地区を 2 地区（備後地区と淡路地区), 計 4 地区を設定 した。なお，調查対象地区は，4 地区共通して 1 街区約 $80 \mathrm{~m}$ 四

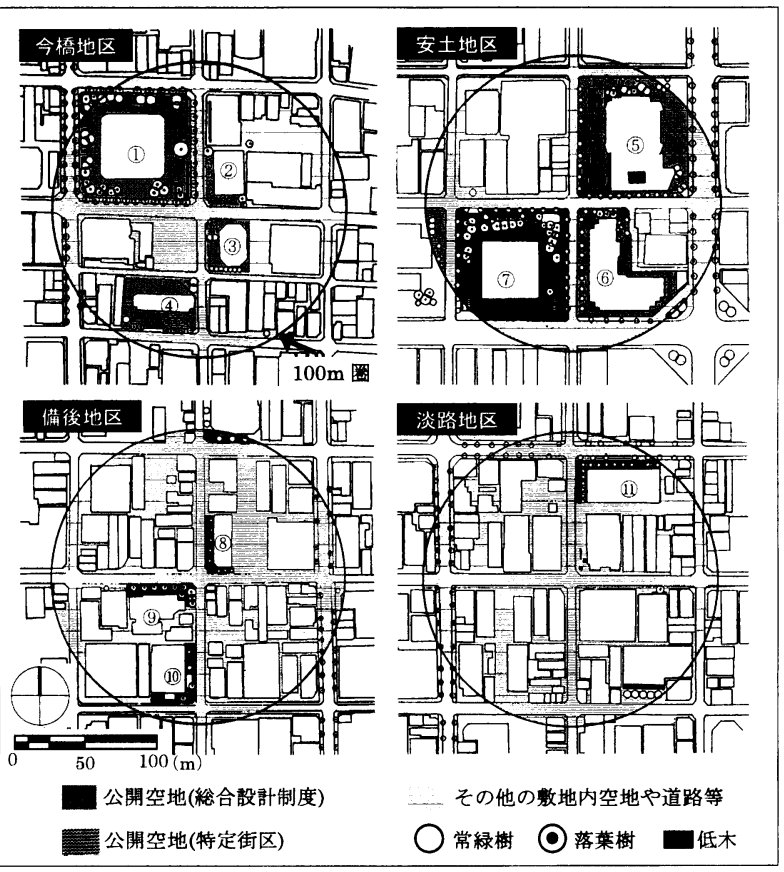

図-1 調査対象地区内の状況

*大阪府立大学農学部地域環境科学科 ${ }^{* *}$ 大阪府立大学大学院農学生命科学研究科 
方の 4 街区で構成され， 街路幅員も南北街路約 6 $\mathrm{m}$, 東西街路約 $8 \mathrm{~m}$ とほ ぼ同じである（図-1参 照)。

（ii）緑の集積状況の調 查および解析方法

物的環境調查では，現 地調査ならびに図上調查 $(1: 2,500)$ より 4 地区内 での建築物の高さ, 街路 中心線から主要建築物の

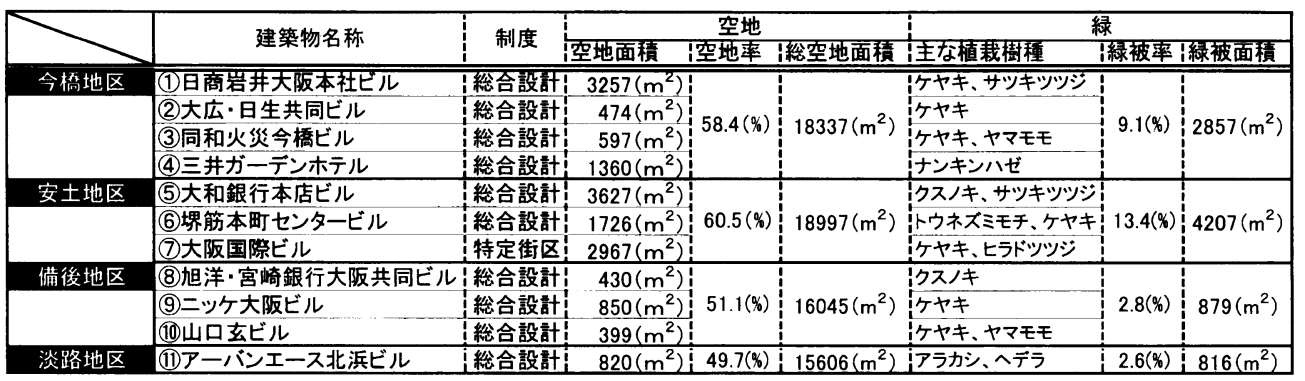

\section{表一 1 調査対象地区内の空地および緑の状況}

壁面までの距離, 街路中心点から緑地・水面を有する中之島公園 までの距離, 植栽の階層構成, 樹種, 樹高, 枝張りを調査した。 さらに，緑の集積状況調查について詳述すると，天空状況調査で は後述する微気像調查時の 11 測定ポイントにおいて, 魚眼レン ズ (Fisheye Nikkor 8mm F2.8) を用いて, 街路に対して水 平上向きに $1.5 \mathrm{~m}$ の高さで写真を撮影した。解析では，撮影した 写真の画面内に占める空, 緑, 構造物, ガラス面の 4 要素ごとの 面積を計測し，11 測定ポイントを平均して面積占有率を算出し， 緑の占有率を用いて研究を進めた。緑被率調査では空中写真 （1992 年 8 月撮影）を用い街路中心点から $100 \mathrm{~m}$ 圈域内での緑被 率を算出した。

\section{（iii）各地区の緑の集積状況}

図一 1 および表 -1 は, 各地区の緑の集積状況之空地の状況を 示し, 図一 2 は南北街路での天空状況を示している。

今橋地区：本地区は，4 地区の中で中之島公園に最も近く（約 $270 \mathrm{~m} ）$ に位置している。総合設計制度による 4 面接道した街区 である日商岩井大阪本社ビルの公開空地を中心に緑化が施されて いる。100m圈域の緑被率は $9.1 \%$ 之安土地区に次いで高く，南 北街路での天空に占める緑の占有率は $20.7 \%$ となっており緑豊 かな地区である。

安土地区: 本地区は, 中之島公園から約 $970 \mathrm{~m}$ 之最も遠くに位 置している。特定街区制度による大阪国際ビルの公開空地，総合 設計制度による堺筋本町センタービル，大和銀行本店ビルの公開 空地が全て $1,000 \mathrm{~m}^{2}$ 以上である。100 $\mathrm{m}$ 圈域の緑被率は $13.4 \%$ 之 最も高く, 南北街路での天空に占める緑の占有率は $16.6 \%$ 之高 くなっている。

備後地区 : 本地区は，中之島公園から約 $780 \mathrm{~m}$ に位置している。 総合設計制度による旭洋・宮崎銀行大阪共同ビル, ニッケ大阪ビ ル, 山口玄ビルの 3 力所は, $1,000 \mathrm{~m}^{2}$ 末満の歩道上公開空地であ

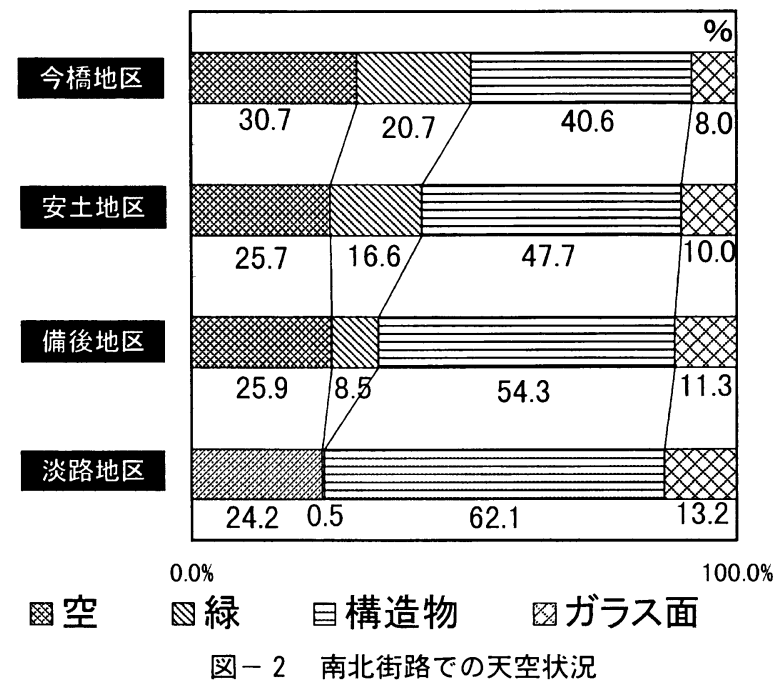

る。100m圈域の緑被率(2.8\%), 南北街路での天空に占める緑の 占有率 (8.5\%) は共に低い。

淡路地区：本地区は，中之島公園から約 $690 \mathrm{~m}$ に位置し，公開 空地を中心とする民有地での緑化はほとんど存在しない。その中 で, アーバンェース北浜ビルはこの地区内で唯一の総合設計制度 適用建築物である。 $100 \mathrm{~m}$ 圈域の緑被率は $2.6 \%$ 之最低で, 南北 街路での天空に占める緑の占有率は $0.5 \%$, 緑はほとんど存在 しない。

\section{（2）調查および解析方法}

(i) 微気像調査（気温・湿度）

本調查は，気温と湿度を 1997 年 8 月 17 日，同年 10 月 19 日， 同年 12 月 14 日に，4 地区同時に 4 つの測定機器を用いて， 9 時 台から 17 時台にそれぞれ約 30 分間移動計測を行った。測定ポイ ントは, 各地区とも日陰の影響を受けやすいと考えられる南北街 路を対象に, 街路中心点（直交街路の交差点）を基準とし南北方 向それぞれ $50 \mathrm{~m}$ 地点まで $10 \mathrm{~m}$ 間隔で 5 ポイントずつ設定した。 従って, 調査対象区間は $100 \mathrm{~m}$, 調查ポイントは街路中心点を含 めて 11 ポイントである。調査では, 各地区とも最も北側の測定 ポイントにおいて，樹影や建築物の輻射熱の直接的な影響を避け るために南北街路の中心線上において $1.5 \mathrm{~m}$ の高さで測定を開始 し, 各ポイント約 2 分間気温と湿度を测定し, 順に南下し計 11

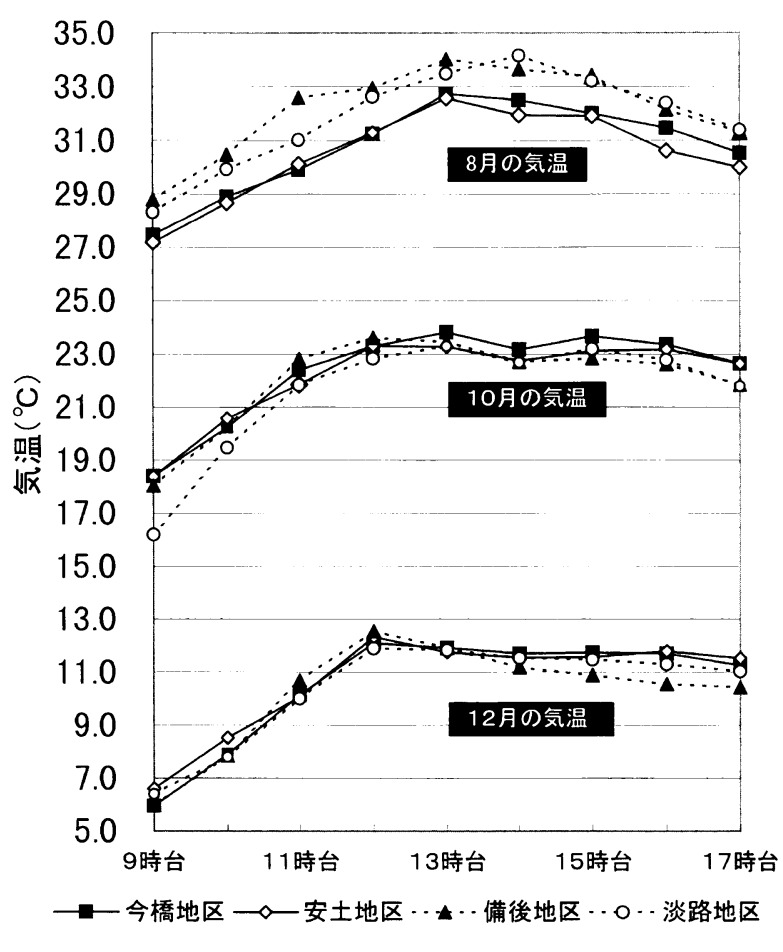

図-3 微気象特性（気温） 
ポイント測定を行い基礎データとした。解析では, 各ポイントの 測定值に器差補正を加え平均值を算出し, さらに地区間での平均 值の差の有意差を危険率 $5 \%$ で検定した。

なお，湿度に関しては，緑の集積状況と明確な関係を見いだせ なかったので考察から省いた。

測定に用いた機器は, 神栄(株)TRH-CX デジタル温湿度計, 神栄(株)TRII-CZ デジタル温湿度計, ヴァイサラ湿度温度指示 計，盟和商事(株)HMI-31 温湿度計である。これら 4 台は，3 時 期それぞれの調査日 2 ～ 3 日前に，大学構内の環境条件の異なる 15 力所において 4 台とも同一条件下で気温・湿度を測定し，そ れらの相関関係からその補正值を求めて器差補正した。

(ii) 鳥類出現状況調査

本調查は，緑の集積状況之の関連のみならず，温度と鳥類生息 との関連性も見るために，微気象調査之同月に各月 4 回，地区の 東西街路之南北街路を調査ルートとしたルートセンサス法 ${ }^{9)}$ で, 観测者から $25 \mathrm{~m}$ 以内に出現した鳥類の鳥種，個体数を記録した。 天候は, 晴れもしくはうす皐りの日を選び, 調查時間は午前 7 時

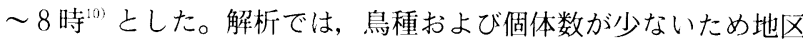
ごとに計 12 回の調查結果を合計し地区別の出現鳥種数，出現個 体数として算出した。なお，温度之出現状況之の明確な関連は見 られなかったので考察は省いた。

\section{（iii）景観評定調查}

本調查では, 調查対象地区の南北街路北端から街路中心点（交 差点）まで，ビデオカメラ（Victor GR-T707）を用い歩行速 度でほぼ歩行者の視点で撮影し，同様に東西街路西端，南北街路 南端，東西街路東端からも街路中心点まで撮影した画像を刺激媒 体として評定を行った。撮影は，画角を $50 \mathrm{~mm}$ ，焦点を無限大と し 1997 年 10 月に行った。本来，対象地区の利用者に対して評定 調査を行うべきであるが，ここでは専門のバイアスがかかってい るということを前提として, 専門的意識の高い本学農学部の学部 生之大学院生総数 23 人を被験者として, 室内で 29 型テレビ （Victor AV-M2905）に刺激画像を映し実施した。

調査では，景観に対するデザイン面，空間量，修景面等を考慮 し, 当該研究メンバーによるブレーンストーミングを通じて, 『リズム感』『調和』『個性』『美しさ』『親しみ』『ゆとり』『㕕が り』『開放感』を評価項目とし, 各項目をどの程度感じるかを「非 常に感じる」〜感じない」の 4 段階で質問した。解析では, この 4 段階の評価尺度に 3 点〜 0 点の評価点を与え基礎データとし，

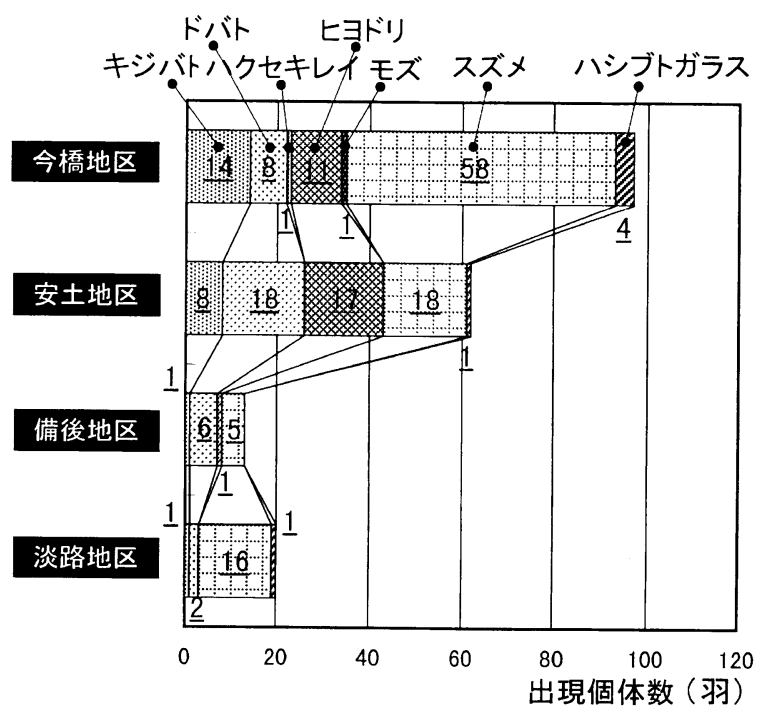

図-4 鳥類の出現状況
このデータを基に平均評価点と標準偏差を算出し，さらに地区間 で平均值の差の検定（５％）を行った。

\section{3. 解析および考察結果}

（1）微気象に及ぼす効果（気温・湿度）（図 -3 参照 $)$

8月の測定において, 気温は緑が集積している今橋, 安土の両 地区と緑が集積していない備後，淡路の両地区間とに全時間帯を 通じて有意差が確認され, 今橋, 安土の両地区の方が備後, 淡路 の両地区に比べ $0.6 \sim 2.7^{\circ} \mathrm{C}$ 低くなっているこよから気温の上昇の 抑制効果が確認された。さらに，緑が散在している備後地区之淡 路地区とを比較すると, 緑被率は両地区とも $3 \%$ 末満と少ないも の南北街路の天空に占める緑の占有率が $8.5 \%$ 之街路沿いに樹木 が存在する備後地区に打いても気温上昇の抑制効果は見られなかっ た。このことから, 天空に占める緑率が $8 \%$ 程度では気温上昇の 抑制には影響を及ぼさず，ここでは $100 \mathrm{~m}$ 圏域内での緑被率が影 響していることが推察される。

12 月の測定において, 気温は，8月の測定と同様に緑が集積 している今橋, 安土の雨地区の方が緑の集積が見られない備後, 淡路の両地区に比べ 16,17 時台に $0.2 \sim 1.2^{\circ} \mathrm{C}$ 有意に高くなって いることから, 緑の集積している地区での気温低減の抑制が一部 確認された。

なお，10月の測定結果は 12 月の測定結果と類似しているもの の, 各地区間の気温幅は小さくなった。

以上のことから, 緑の集積により, 特に屋外環境の厳しい夏李 に, 微気象の緩和効果が顕著に発揮されるものと考えられる。

（2）鳥類出現に及ぼす効果（网 -4 参照）

緑が集積している今橋地区では, 鳥種数, 個体数とも 4 地区の 中で最も多く 7 種 97 羽が確認され, また唯一, 八クセキレイが 確認された。八クセキレイは最近都市鳥化しつつある鳥種である あのの, 本調相で確認された鳥種の中では最も野生度の高い鳥種 である。このことは, 今橋地区の緑被率が $9.1 \%$ と高く, しかも 鳥類の生息空間が確保されている中之島公園に最も近いことが関 係しているものと考えられる。

また, 緑が集積している安土地区で 5 種 62 羽, 緑が集積して いない備後, 淡路地区でそれぞれ，4 種 13 羽，4 種 20 羽が確認 された。この 3 地区を比較すると, 種数は同程度であるものの個 体数は著しく異なっていた。安土地区は, 中之島公園から遠方に 位置するため種数はほぼ他 2 地区と同じであるが, 緑被率が 13.4

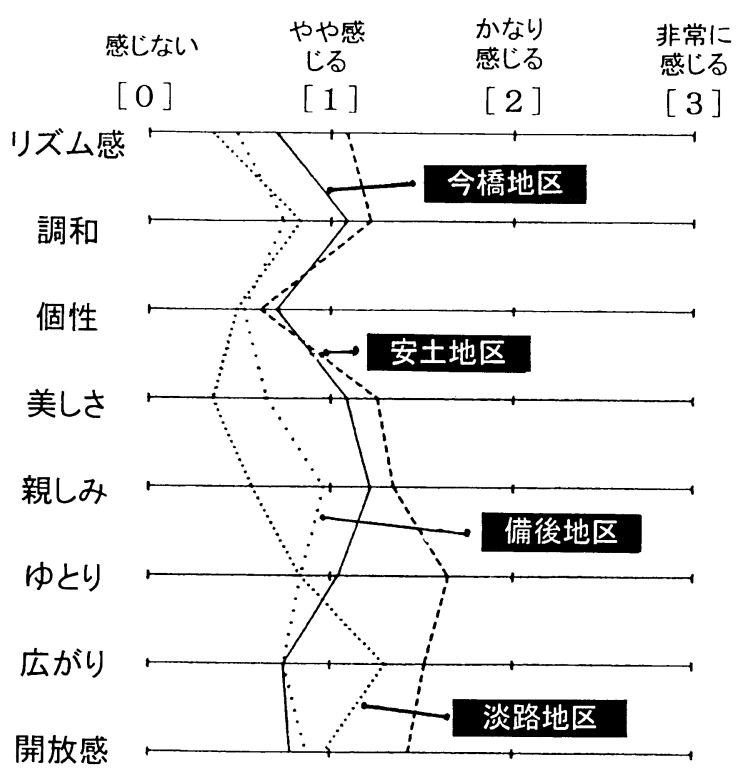

図- 5 景観評価結果 
\%と大きいため都市鳥の生息に適した環境を形成していることが 推察できる。

（3）景観評価に及ぼす効果（図一 5 参照）

安土地区は, 『個性』を除くすべての評価項目に対し平均評価 点が 1 点以上と高く評価され，4地区の中で最も良好な沿道景観 を呈しているといえる。しかし,『ゆとり』(1.65点), 『広がり』 (1.52 点), 『開放感』(1.43 点)に対する評価は有意に高い值を示 した。これは, 緑の集積による効果というよりも $1,000 \mathrm{~m}^{2}$ 以上の 大規模な公開空地の存在に起因して, 空間量に関する項目の評価 が高くなったためと考えられる。今橋・安土の両地区では『美し さ』の評価がそれぞれ 1.09 と 1.26 点, 『親しみ』が 1.22 点と 1.35 点と高くなっている。よって, 緑の集積による緑量の豊か さが『美しさ』や『親しみ』といった修景に関する評価を高める という修景効果を発揮していることが確認できた。また, 緑の集 積が低い淡路地区之備後地区とを比較すると, 天空に占める緑の 占有率の大きい備後地区の方が『美しさ』(0.65 点) と『親しみ』 (0.96 点) の評価が高かった。このことから, 街路沿いの頭上を 覆うような高木植栽が, 修景に関する評価を高める要因であると 考えられる。

\section{4.おわりに}

以上の結果から，まず， $100 \mathrm{~m}$ 圏域といった数街区レベルでの 緑の集積状況の違いによって対象地区内部における環境保全に係 わる効果にかなりの差のあることがわかり, 都心部においてはそ の効果に地域差を生じていることが明らかとなった。

具体的には, $100 \mathrm{~m}$ 圏域内の緑被率が $9 \%$ を越えるような緑の 集積した地区において, 夏季で最高 $2.7^{\circ} \mathrm{C}$ の気温上昇を抑制し, 冬季での夕刻に最高で $1.2^{\circ} \mathrm{C}$ 気温低減を一部抑制するといった微 気象の緩和効果が発揮されている。特に，その効果は夏季におい て顕著であることが実証された。また，この緑被率は鳥類の出現 状況にも影響を及ぼし, 緑が集積している2 地区ほど個体数が多 く, 種数もやや多くなっている。景観面では, 緑が集積した 2 地
区は言うに及ばず，備後地区のように緑被率が低い場合でも天空 での緑の占有率が比較的高い場合に, 美しさや親しみの評価がや や高くなる傾向がある。よって, 緑化する際にはまず, 街路沿い に樹冠の大きな高木を植栽することが修景効果をより発揮させう るものと考えられる。一方, 安土地区の例に見られたように, 緑 の集積していることによって生じた効果というより，1,000 $\mathrm{m}^{2}$ を 大幅に越える大規模な公開空地が存在していることによって, 景 観評価における空間量に係わる評価を向上させるといった効果む 確認され，公開空地の設置に際しては十分な空間量確保の必要性 が示唆できる。

これに対し，100m圈域内の緑被率が $3 \%$ 未満と低い場合，街 路の天空に占める緑の占有率が $8 \%$ 程度では, 微気象を緩和させ る直接的な要因にはならず，鳥類の出現に与える影響も少ない。 今後, 計画的に緑化スペースとしての空地を確保し, そこでの 緑を集積させていく制度として, 特定街区や総合設計での公開空 地がますます重要な位置づけとなるといえる。特に, 前述したよ うに, 敷地単位だけではなく街区単位での空地や緑の総量を規定 したり目標值を掲げていくことが必要になると考える。さらに, 今回の研究で取り上げたように, 連担しあう街区が空地量や緑量 の過不足を補完しあいながら，緑を集積させていくことで，その 街区周辺の環境保全に係わる各種の効果を発揮させ地域間の差を 解消できるむのと考える。

本研究では, 調查対象地区が 4 地区と少なかったため, $100 \mathrm{~m}$ 圈域内での緑の集積に係わる空地量や緑量の具体的数值を示すこ とができなかった。従って, 緑の集積程度の異なる調查対象地区 をさらに増やすことで, 環境保全に関する各種の効果を発揮させ ることのできる緑の集積程度を定量化していくことが可能となる と考える。また, 調査対象地区周辺の街区の状況が各種の効果に 影響を及ぼすかどうかについては，今回の $100 \mathrm{~m}$ 圈域を $200 \mathrm{~m}$ 圈 域, $300 \mathrm{~m}$ 圏域といったように広げ，街区単位を計画単位と位置 づけながら効果の及ぶ圈域を探ることも重要であると考える。

\section{参考文献}

1) 野島義照・島尾勝 (1989)：公開空地等 における緑地空間の整備の動向 : 造園 雑誌 52(5)，306-311

2 ) 丸田頼一(1973)：公園緑地内の気象 : 造園雑誌 37(5)，33-55

3 ) 西田 勝・片山忠久 ・石井昭夫・林 徹夫・堤純一郎・塩月義隆・北山広樹 (1989):公園緑地の暑熱緩和効果に関 する実測調查:日本建築学会大会学術 講演梗概集, 1089-1090

4) 尹 龍漢 - 丸田頼 - ・柳井重人(1997):
公園緑地内における気温及び相対湿度 分布之土地被覆状態との関連性につい て:第 11 回環境情報科学論文集, 19-24

5 ) 尹 龍漢・丸田頼一・本條 毅・柳井 重人(1998)：都市における公園内外の 気温分布特性について:ランドスケー プ研究 61(5), 769-772

6 ）山田宏之・丸田頼一(1989) : 都市にお ける緑地の気象緩和作用についての実 証的研究：造園雑誌 52(5)，127-132

7 ）山田宏之・丸田頼一(1991)：緑地によ る都市気象緩和作用の定量的解析 : 造
園雑誌 54(5)，299-304

8 ）下村泰彦・増田 昇・山本 聡・有田 義隆(1998）：公開空地を対象とした民 有地での連続緑化が果たす環境保全に 係わる効果に関する研究 : ランドスケー プ研究 61(5)，685-688

9 ）樋山広芳他(1982）：森林面積と鳥の種 類との関係: Strix $1,70-78$

10）由井正敏 (1978)：森林原野性鳥類のラ インセンサス法の研究・1 記録率の日 周変化: 山階鳥類研究所報告 $10(1,2)$, 70-81

Summary: This study is aimed to make clear that the environmental conservation effect of the large amount of greenery within the area of $100 \mathrm{~m}$, comparing Imabashi district and Azuchi district where there are many plants with Bingo district and Awaji district where there are few plants. It is concluded that $0.6-2.7^{\circ} \mathrm{C}$ are lower in August and $0.2-1.2^{\circ} \mathrm{C}$ are higher in December in the temperature at the districts which have the large amount of greenery. More species and individuals of birds are observed at the districts with the large amount of greenery than at other districts. About the landscape evaluation, most of the landscape evaluating items of Azuchi district are much higher. In this way, it was confirmed that the large amount of greenery has the environmental conservation effect. 